\title{
MEMBANGUN KREATIVITAS DAN KEMANDIRIAN MASYARAKAT DI MASA PANDEMI COVID - 19
}

\author{
Laura Komala, Arief Budiyanto, Wahyu Andri Wibowo, Alvin Praditya, \\ Ibrahim Bali Pamungkas \\ Universitas Pamulang \\ Email:dosen01013@unpam.ac.id
}

\begin{abstract}
COVID-19 is a virus that causes disorders of the respiratory system, severe lung infections that can cause death. The Indonesian pandemic shows that the current 19 escalation continues to increase. Not only does it involve the economy, but this virus not only causes the death rate to be saved by the world but also causes an economic slowdown that slows the "killing" of countries in the world and also calculates a large amount of yield. In a world that is highly connected and integrated, influencing disease that eliminate death (those who die) and morbidity (those who cannot work for a certain period of time) have been very clear since this covid-19 outbreak. This Community service is entitled building community creativity and independence in the covid-19 pandemic period the general objective of community service activities is to help the people of Pondok Jaya Village, pondok Aren subdistrict, South Tangerang City in helping the economic community ahead of the new normal area.
\end{abstract}

Keywords: Creativity, Independence, Pandemic, Covid-19

\begin{abstract}
Abstrak
COVID-19 adalah virus yang menyebabkan gangguan pada sistem pernapasan, infeksi paru-paru yang berat hingga dapat menyebabkan kematian. Di indonesia pandemic covid 19 yang saat ini terus mengalami eskalasi. Tidak hanya berpotensi meengakibatkan kontraksi pertumbuhan ekonomi, serta virus ini tidak hanya menyebabkan tingginya angka kematian diseluruh dunia tetapi juga menyebabkan merosotnya ekonomi yang perlahan "membunuh" negara-negara di seluruh dunia dan juga mengakibatkan jumlah pengangguran dalam jumlah yang besar. Dalam dunia yang sangat terhubung dan terintegrasi, dampak penyakit diluar kematian ( mereka yang meninggal) dan morbiditas (mereka yang tidak dapat bekerja untuk jangka waktu tertentu) telah terlihat sangat jelas sejak adanya wabah covid-19 ini. Pengabdian Kepada Masyarakat ini berjudul Membangun Kreativitas dan Kemandirian Masyarakat di Masa Pandemi Covid-19 Tujuan umum dari kegiatan pengabdian kepada masyarakat ini adalah membantu masyarakat Kelurahan Pondok Jaya
\end{abstract}


Kecamatan Pondok Aren Kota Tangerang Selatan dalam meringankan beban ekonomi masyarakat jelang era new normal.

Kata Kunci: Kreativitas, Kemandirian, Pandemic, Covid-19

\section{A. PENDAHULUAN}

Kewirausahaan dan UMKM adalah "anak tiri" dari perekonomian Indonesia Karenawalaupun sektor ini menyerap banyak sekali tenaga kerja namun entah kenapa pemerintah kita (sebelumnya) kurang begitu memperhatikan dan membantu perkembangan para pelaku wirausaha dan UMKM. Berdasarkan data UMKM tahun 2012 dari Kementerian Koperasi dan UKM Republik Indonesia, sektor UMKM menyumbang sekitar 59.08\% dari GDP Indonesia - sekitar 528.7 milyar USD - dan menyerap $97.16 \%$ tenaga kerja - 107 juta tenaga kerja. Melihat angka ini, kita bisa lihat betapa pentingnya kontribusi UMKM terhadap perekonomian Indonesia. Namun sayangnya pemerintah kita tidak memiliki kebijakan komprehensif untuk membantu perkembangan wirausaha dan UMKM. Memang ada beberapa kebijakan pro UMKM, seperti Kredit Usaha Rakyat (KUR), yang sudah dimulai oleh pemerintahan era SBY. Namun dampaknya masih kurang terasa karena pada faktanya hanya sekitar 25\% (13 juta) dari pelaku UMKM yang sudah bisa mendapatkan akses ke lembaga finansial (bank). Selain itu, kebijakan yang dikeluarkan oleh pemerintahan SBY hanyalah menyentuh satu aspek, yaitu pembiayaan. Padahal ada banyak aspek yang perlu distimulasi oleh pemerintah untuk mengembangkan sektor wirausaha dan UMKM lebih lanjut.

Di antara berbagai faktor penyebabnya, rendahnya tingkat penguasaan teknologi dan kemampuan wirausaha di kalangan UMKM menjadi isue yang mengemuka saat ini. Pengembangan UMKM secara parsial selama ini tidak banyak memberikan hasil yang maksimal terhadap peningkatan kinerja UMKM, perkembangan ekonomi secara lebih luas mengakibatkan tingkat daya saing kita tertinggal dibandingkan dengan negara-negara tetangga kita seperti misalnya Malaysia. Karena itu kebijakan bagi UMKM bukan karena ukurannya yang kecil, tapi karena produktivitasnya yang rendah. Peningkatan produktivitas pada UMKM, akan berdampak luas pada perbaikan kesejahteraan rakyat karena UMK adalah tempat dimana banyak orang menggantungkan sumber kehidupannya. Salah satu alternatif dalam meningkatkan produktivitas UMKM adalah dengan melakukan modernisasi 2 sistem usaha dan perangkat kebijakannya yang sistemik sehingga akan memberikan dampak yang lebih luas lagi dalam meningkatkan daya saing daerah

Berangkat dari latar belakang tersebut, tim Dosen dari Program Manajemen Universitas Pamulang mengadakan kegiatan Pengabdian kepada Masyarakat dengan bermitra bersama warga di Kelurahan Pondok Jaya Kecamatan Pondok Aren Kota Tangerang Selatan untuk dapat memberikan pengajaran bahasa bagi para siswa. Selagi tim Abdimas memberi pengarahan kepada warga di Kelurahan Pondok Jaya Kecamatan Pondok Aren Kota Tangerang Selatan dapat mengadaptasi proses masukan, hingga kedepannya program ini dapat berkelanjutan.

Kegiatan pengabdian masyarakat ini diharapkan dapat memberikan manfaat bagi peserta pelatihan maupun bagi para Civitas Akademika Prodi Manajemen.

1. Manfaat bagi para peserta dalam kegiatan ini adalah diharapkan dapat mengenali, memahami, dan mengaplikasikan manajemen berbasis aktivitas usaha kecil dan menengah dalam kegiatan sehari-hari 
2. Manfaat bagi civitas academica, kegiatan ini diharapkan dapat menjadi tempat untuk mengamalkan ilmu ekonomi manajemen sebagai wujud peran serta secara nyata pengabdian diri kepada masyarakat

\section{B. METODE PELAKSANAAN KEGIATAN}

\section{Tahap Pertama}

Dalam rangka memecahkan masalah yang dihadapi warga, maka tim pengabdian Universitas Pamulang melaksanakan kegiatan mengaplikasikan manajemen berbasis kreativitas dan kemandirian masyarakat dimasa pandemi covid-19 dengan warga di Kelurahan Pondok Jaya Kecamatan Pondok Aren Kota Tangerang Selatan. Proses pembahasan akan dilakukan dengan metode komunikatif sesuai dengan perkembangan kognitif pengajaran.

\section{Tahap Kedua}

Tahap ini merupakan pelaksanaan kegiatan. Kegiatan ini dilakukan bersamasama oleh masyarakat sesuai dengan yang telah direncanakan. Sedangkan tim pengabdian masyarakat akan bertindak sebagai fasilitator.

\section{Tahap Ketiga}

Pada tahap ini dilakukan monitoring dan evaluasi kegiatan. Proses ini juga dilakukan sendiri oleh masyarakat.merupakan pelaksanaan kegiatan. Kegiatan ini dilakukan bersama-sama oleh masyarakat sesuai dengan yang telah direncanakan. Sebagai tim pengabdian masyarakat hanhya bertindak sebagai fasilitator.

\section{HASIL DAN PEMBAHASAN}

Untuk mengatasi hal ini diperlukan usaha berbagai pihak untuk lebih menggalakkan jiwa peduli terhadap masyarakat dan UMKM yang ada di sekitar. Beberapa tips yang didapatkan ileh tim pengabdi agar para UMKM dapat bertahan dimasa pandemic menurut standee (2020) menyatakan ada 5 (Lima) tips agar para UMKM dapat bertahan dimasa pandemic yaitu:

1. Manfaatkan media social sebagai channel utama pemasaran. Di tengah himbauan menjaga social distancing, media social dapat menjadi salah satu cara dalam mempromosikann produk atau usaha yangkamu miliki jika kamu belum mencobanya

2. Selalu monitor transaksi bisnis. Lakukan transaksi perbankan secara online di rumah. Melalui fitur Cash Link pada Jurnal, pemilik usaha dapat melakukan rekonsiliasi bank secara otomatis tanpa perlu repot mengunjungi kantor fisik. Jurnal akan menampilkan ringkasan rekonsiliasi bank pada semua akun kas dan bank, serta perubahan saldo kas dan bank yang belum dicatat.

3. Perhatikan kondisi stok barang. Cek status persediaan barang secara berkala dan real time. Menggunakan fitur Inventory Jurnal, pemilik usaha tidak hanya menghitung persediaan barang, tetapi juga mengetahui harga jual beli rata-rata, dan menginformasikan ketersediaan stok saat itu juga. 
Target

Kontribusi mendasar dari kegiatan ini adalah agar masyarakat dapat berkreativitas dan mendiri dimasa pandemi covid-19.

\section{Lokasi}

Sasaran program pengabdian masyarakat yang akan dituju adalah masyarakat RT 005 / 002 Kelurahan Pondok Jaya Kecamatan Pondok Aren Tangerang Selatan.

\section{IPTEK yang ditransfer}

Industri Kreatif dan Mandiri adalah suatu konsep bagaimana ekonomi kreatif dan mandiri bekerja, serta presentasi konsep "Triple helix" untuk pondasi pilar ekonomi kreatif dan mandiri.

Triple helix adalah sebuah konsep yang mengsinergikan tiga elemen yaitu pemerintah,pelaku usaha dan kamu intelektual agar bersatu padu membentuk sebuah lingkaran harmonis satu sama lain dengan tujuan membentuk ekosistem yang baik dan efektif bagi para pelaku usaha agar dapat mengembangkan usahanya. Dengan demikian diharapkan dapat menciptakan seorang wirausaha baru.

\section{Luaran Target}

Target luaran dari kegiatan ini adalah masyarakat dapat berwirausaha sejak dini melalui aktivitas kegiatan kelompok masyarakat berwirasuaha serta pemanfaatan teknologi. Pencapaian dalam program PKM ialah :

1. Masyarakat mampu membantu UMKM yang berada dilingkungan sekitar.

2. Dalam pelaksanaan penyuluhan berkreativitas dimasa pandemi bagi masyarakat dan UMKM, adanya kegiatan yang dilakukan dalam peningkatan daya beli dan saling memberi.

3. Masyarakat mampu mendeteksi kelemahan kegiatan yang telah dilakukan dengan cara monitoring dan evaluasi kegiatan.

\section{KESIMPULAN DAN SARAN}

\section{Simpulan}

Kegiatan pengabdian masyarakat ini di laksanakan di RT 005 / 002 Kelurahan Pondok Jaya Kecamatan Pondok Aren Kota Tangerang Selatan. Pada kegiatan pengabdian masyarakat ini, diimplementasikan gerakan masyarakat membangun perekonomian di lingkungan masyarakat. Masyarakat sasaran kegiatan adalah warga RT 005 / 002keluarahan Pondok Jaya sebuah keluarahan yang berada dalam naungan kecamatan Pondok Aren kota Tangerang Selatan. Dimasa pandemi COVID 19 ini banyak warga yang membutuhkan bantuan sosial tetapi masih kurangnya kepedulian masyarakat terhadap itu. Kesempatan tersebutkami manfaatkan untuk dapat memfasilitasi dan membina masyarakat.

\section{Saran}

Dengan adanya kegiatan penyuluhan ini semoga bisa menambah wawasan serta semangat dalam menghadapi masa pandemic supaya tetap berkreativitas dan kemandirian 
supaya tidak ketergantungan terhadap bantuan yang belum pasti. Tetap berusaha dan berjuang, karena semua musibah pasti bisa dilalui.

\section{Ucapan Terima Kasih}

Rasa Terimakasih kami haturkan kepada segenap pihak yang telah ikut membantu lancarnya kegiatan Pengabdian Kepada Masyarakat dengan judul "Membangun Kreativitas Dan Kemandirian Di Masa Pandemi” kepada:

1. Rektor Dr. H. Dayat Hidayat, M.M, Rektor Universitas Pamulang Tangerang Selatan Banten.

2. Dr. Ali Maddinsyah, S.E., M.M., selaku Ketua LPPM Universitas Pamulang Tangerang Selatan - Banten.

3. Dr. Kasmad, S.E., M.,M., selaku Ketua Program Studi Manajemen Universitas Pamulang Tangerang Selatan - Banten.

4. Dr. Udin Ahidin, S.E., M.M., C.M.A, Selaku Wakil Program Studi Manajemen Universitas Pamulang Tangerang Selatan - Banten.

5. Drs. Waluyo Jati, M.M., Selaku Sekretaris Program Studi Manajemen Universitas Pamulang Tangerang Selatan - Banten.

6. Fery Ismail, selaku Ketua RT 005/002 Kelurahan Pondok Jaya, Kota Tangerang Selatan Banten.

\section{DAFTAR PUSTAKA}

Binwasnaker \& K3. 2020. Menaker Beri Bantuan Bagi Korban PHK dan Dirumahkan. https://kemnaker.go.id/news/detail/menaker-beri-bantuan-bagi-korban-phk-dandirumahkan. 29 Juni 2020.

Humas Kemensetneg. 2020. Upaya-upay Pemerinth Penuhi Kebutuan Pokok Masyarakat di Tengah Pandemi COVID-19

Pane, Merry Dame Cristy. (2020). COVID-19. https://www.alodokter.com/covid-19. 29 Juni 2020 .

Standie. (2020). Tips Agar Pelaku UMKM Bisa Bertahan Hadapi Krisis Akibat Pandemi Virus Corona. https://personalfinance.kontan.co.id/news/ini-tips-agar-pelaku-umkmbisa-bertahan-hadapi-krisis-akibat-pandemi-virus-corona?page=all. 29 Juni 2020. 